\title{
Interactions of Soybean Lectin, Soyasaponins, and Glycinin with Rabbit Jejunal Mucosa In Vitro
}

\author{
JOSE R. ALVAREZ AND RAMON TORRES-PINEDO ${ }^{(22)}$ \\ Department of Pediatrics, University of Oklahoma Health Sciences Center, University of Oklahoma, Oklahoma City, \\ Oklahoma USA
}

\section{Summary}

Mucosal samples from rabbit jejunum were incubated $(30 \mathrm{~min}$, $\left.25^{\circ} \mathrm{C}\right)$ with $\left({ }^{125} \mathrm{I}\right)$ glycinin in the presence of buffer, soybean lectin $(50 \mu \mathrm{g} / \mathrm{ml})$ soyasaponins $(1 \mathrm{mg} / \mathrm{ml})$, or both lectin and saponins. The mucosal uptake of $\left({ }^{125} \mathrm{I}\right)$ glycinin was negligible with buffer, and increased progressively with additions of soybean lectin $(P<$ $0.05)$, soyasaponins $(P<0.005)$, and both $(P<0.0001)$. The stimulation of uptake by lectin and saponins together was greater than the sum of their individual effects $(P<0.0005)$. The effect of soybean lectin on glycinin uptake was concentration dependent, reaching a maximum at approximately $50 \mu \mathrm{g} / \mathrm{ml}$ for the stimulation of uptake in the presence of saponins, and was inhibited by $D$ GalNAc. Although the mechanisms involved in mucosal uptake of glycinin cannot be described from these data, we have assumed the presence of two independent pathways for lectin-stimulated and saponin-induced uptakes. In addition, we have proposed that soybean lectin, by binding to terminal galactoside sites at the enterocyte apical membrane, enhances a crenator effect of saponins that leads to increasing leakage of glycinin into the cell.

\section{Speculation}

Soyasaponins are heat resistant and their cellular lytic and trypsin inhibiting activities are known to increase after heat processing. Soybean lectin is heat labile, but remains at appreciable concentrations in inadequately processed and crude soy extracts. Interactions and effects similar to those occurring with mucosal tissues in vitro could also take place in the jejunum in vivo upon ingestion of such soy products.

Studies on the transport of macromolecules in the small bowel of mammals have been mainly concerned with endocytosis. This has led to increased understanding of the epithelial mechanisms of transmembrane transfer and cytoplasmic transport of immunoglobulins $(7,10)$, antigen-antibody complexes (1), and proteins such as horseradish peroxidase and serum albumin $(17,18,19)$. In contrast, nonendocytic macromolecular leakage into intestinal mucosa has not been adequately investigated.

This paper presents an in vitro model of macromolecular penetration into rabbit jejunal mucosa using three components of the soybean; namely, soybean lectin (SBA), soyasaponins, and glycinin. SBA is a tetramer protein with two binding sites of high specificity for N-acetyl-D-galactosamine and D-galactose (8); soyasaponins are a heterogenous mixture of triterpenoid glycosides having sapogenol B as the aglycone, and glucuronic acid, arabinose and terminal rhamnose or galactose as carbohydrates $(3,20)$; glycinin is the major storage protein of the soybean (2). We present evidence indicating that SBA and soyasaponins cooperate at the epithelial surface to stimulate the mucosal uptake of labeled glycinin.

\section{MATERIALS AND METHODS}

Reagents. Soybean lectin, N-acetyl-D-galactosamine, and Lrhamnose were purchased from Sigma Chem. Co., (St. Louis, MO). Soyasaponins were isolated, as described by Birk et al. (4), from defatted soyafluff, a gift from Central Soya Co., (Chicago, IL). Glycinin was prepared according to Thanh and Shibasaki (16), and purified further by gel filtration on Sephadex G-200. The final product gave a molecular weight of $325,000 \pm 20,000$ on density polyacrylamide gel electrophoresis. Dissociation into monomers at low ionic strength (16), N-terminal analysis (21), and amino-acid analysis (6), gave expected values. Thin-layer chromatography (chloroform-methanol-water, 66:25:4) of alcohol extractables from glycinin revealed contamination by saponins, phosphatidylcholine, and genistein. These were removed by incubation $\left(1 \mathrm{~h}, 37^{\circ} \mathrm{C}\right)$ with equal weights of bovine serum albumin in $3 \mathrm{ml} 30 \mathrm{mM}$ Tris- $\mathrm{HCl}, \mathrm{pH} 8.0$, followed by precipitation of glycinin at $\mathrm{pH} 6.4$ with $0.1 \mathrm{~N} \mathrm{HCl}$. After centrifugation, the supernate was removed and the precipitate was treated with albumin and precipitated twice more as described above. The purified glycinin was washed with cold water, lyophilized, then extracted with $1.5 \mathrm{ml} 87 \%(\mathrm{v} / \mathrm{v})$ ethanol and concentrated by evaporation. Thin-layer chromatography revealed absence of contaminants.

$\left.{ }^{125} I\right]$ glycinin was prepared by a micromodification of the lactoperoxidase method using the Enzymobead ${ }^{\mathrm{TM}}$ Radioiodination Reagent Kit from Bio-Rad Lab., (Richmond, CA). In brief, the reaction mixture contained $0.2 \mathrm{M}$ phosphate buffer $\mathrm{pH} 7.2(50 \mu \mathrm{l})$, glycinin $(4 \mathrm{mg}, 25 \mu \mathrm{l})$, enzymobeads $(50 \mu \mathrm{l}), \mathrm{Na}^{\mathrm{I}}{ }^{25} \mathrm{I}(80 \mu \mathrm{l})$, and $1 \%$ $(\mathrm{w} / \mathrm{v}) \beta$-D-glucose $(25 \mu \mathrm{l})$. The mixture was incubated for $6 \mathrm{~h}$ at $25^{\circ} \mathrm{C}$ and the reaction stopped by centrifugation $(5 \mathrm{~min}, 1400 \times$ g). For desalting, the supernate was applied to a micro-G 25 column prepared as follows: an Eppendorf pipet tip, plugged with siliconized glass wool, was filled within $3 \mathrm{~mm}$ of the top with $\mathrm{G} 025$ in $0.2 \mathrm{M}$ phosphate buffer $\mathrm{pH} 7.2$, and drained. This pipet tip was mounted inside a $1.5 \mathrm{ml}$ Beckman microfuge tube, with the aid of a small collar, and centrifuged to dryness $(5 \mathrm{~min}, 1400$ $\times g$ ). After two desalting runs, the element was counted and the glycinin specific radioactivity determined from duplicate protein recovery measurements with unlabeled protein (average specific activity, $91.9 \mathrm{mCi} / \mathrm{mmole}$; efficiency of $\left[{ }^{125} \mathrm{I}\right]$ counting: $49.4 \%$ ).

Treatment of jejunal samples with soy fractions. A segment of proximal jejunum was excised from recently weaned New Zealand rabbits under ether anesthesia. The bowel was opened lengthwise, washed with gassed $\left(95 \% \mathrm{O}_{2}-5 \% \mathrm{CO}_{2}\right)$ RPMI 1640 and kept in this medium at room temperature. Mucosal samples $(2-3 \mathrm{~mm})$ were cut with curved iris scissors and six pieces transferred to each well of multiwell plates (Falcon Plastics, Los Angeles, CA) containing $1 \mathrm{ml}$ of the above culture medium and $\left[{ }^{125} \mathrm{I}\right]$ glycinin $(15$ pmoles; $1 \times 10^{5} \mathrm{cpm} /$ pmoles). SBA and soyasaponins were added to the dishes as indicated in the corresponding tables and figures. The plates were placed in plastic air-tight boxes continuously gassed with $95 \% \mathrm{O}_{2}-5 \% \mathrm{CO}_{2}$ and shaken on a rotating platform (Fisher Rotator, Fisher Scientific Co., Dallas, TX) at $130 \mathrm{rpm}$ for $1 \mathrm{~h}, 25^{\circ} \mathrm{C}$. Three from each set of six mucosal samples were then washed three times in cold PBS pH 7.4 containing $1 \mathrm{mg} / \mathrm{ml}$ of glycinin, and homogenized in $0.1 \mathrm{M} \mathrm{KOH}$. Trichloroacetic acid was added to a final concentration of $10 \%(\mathrm{v} / \mathrm{v})$ and the mixture allowed to stand at $4^{\circ} \mathrm{C}$ for $2 \mathrm{~h}$. The acid precipitable material was collected on Millipore filters (AP), and washed four times with 5\% trichloroacetic acid and once with $95 \%$ ethanol. The 
radioactivity was counted on a gamma scintillation counter. The remaining three from each set of six samples were washed in PBS containing $1 \mathrm{mg} / \mathrm{ml}$ of glycinin and planted, mucosal side up, on sterile stainless-steel grids (5). The grids were then placed on organ culture dishes (Falcon Plastics, Los Angeles, CA), containing approximately $0.6 \mathrm{ml}$ of RPMI 1640, antibiotics, insulin $(0.5$ $\mathrm{mg} \%)$, and glucose (366 mg\%). The dishes were returned to airtight boxes, gassed for $10 \mathrm{~min}$, sealed and incubated at $37^{\circ} \mathrm{C}$ for $4 \mathrm{~h}$. $\left[{ }^{3} \mathrm{H}\right]$ thymidine $(1 \mu \mathrm{Ci} / \mathrm{ml})$ and $\left[{ }^{14} \mathrm{C}\right]$ leucine $(1 \mu \mathrm{Ci} / \mathrm{ml})$ were added during the last $30 \mathrm{~min}$ of culture. The explants were then removed, washed three times with $1 \mathrm{mM}$ leucine and $1 \mathrm{mM}$ thymidine in cold PBS, and homogenized in $0.1 \mathrm{M} \mathrm{KOH}$. Trichloroacetic acid was added to a final concentration of $10 \%(\mathrm{v} / \mathrm{v})$ and the mixture allowed to stand at $4^{\circ} \mathrm{C}$ for $2 \mathrm{~h}$. The precipitates were resuspended, homogenized and centrifuged at $1000 \times g$ for $10 \mathrm{~min}\left(4^{\circ} \mathrm{C}\right)$. Duplicate $100 \mu \mathrm{l}$ aliquots of the supernate were saved to measure acid soluble radioactivity. The sediments were washed with $10 \%$ trichloroacetic acid twice as described above. The final precipitates were collected on Millipore filters (AP), and washed four times with 5\% trichloroacetic acid and once with $95 \%$ ethanol. The radioactivity in the acid soluble and insoluble material was counted with $3 \mathrm{ml}$ of Aquasol (New England Nuclear, Boston, MA). For blanks, explants treated in the same manner but without radioactivity, were also counted.

Statistics. Statistical differences between control and test samples were analyzed by Student's $t$ test.

\section{RESULTS}

In order to establish the experimental conditions for $\left[{ }^{125} \mathrm{I}\right] \mathrm{gly}$ cinin uptake into jejunal mucosa, we performed several preliminary experiments. First, we demonstrated histologically that the epithelium remained intact by light microscopy in jejunal explants after 60 min of treatment with SBA and soyasaponins (not shown). Second, $\left[{ }^{125} I\right]$ glycinin was quantitatively recovered in acid-precipitable form after incubation with mucosal samples for $1 \mathrm{~h}$ at $25^{\circ} \mathrm{C}$, indicating absence of significant proteolytic release of $\mathrm{ob}^{125} \mathrm{I}$ ] during the incubation. Finally, the SBA- and saponin-treated samples were compared to the control samples as to rates of DNA and protein synthesis after $4 \mathrm{~h}$ in culture. The only difference observed between control and treated samples was a small but significant stimulation of protein synthesis in the SBA-treated explants (Table 1). These experiments therefore demonstrated the viability of the mucosal tissues under the incubation conditions used to measure $\left[{ }^{125} \mathrm{I}\right] \mathrm{glycinin}$ uptake.

Table 2 shows that incubation of mucosal samples with $\left[{ }^{125} \mathrm{I}\right]$ glycinin resulted in negligible uptake of the macromolecule. Adding SBA, soyasaponins, and both together, caused progressive increases in uptake. Moreover, the effect of the two soy components combined was significantly greater $(P<0.0005)$ than the sum of their individual effects.
To demonstrate that membrane-bound $\left[{ }^{125}\right.$ I]glycinin did not represent a significant amount of the total counts shown in Table 2 , we performed two different types of experiments. First, as shown in Figure 1, when we incubated control samples $\left(\left[{ }^{125} \mathrm{I}\right]\right.$ glycinin alone) and samples treated with SBA and saponins in $1 \mathrm{mg} / \mathrm{ml}$ unlabeled glycinin for variable periods, the predicted differences in $\left[{ }^{125} \mathrm{I}\right]$ glycinin uptake were established after $2 \mathrm{~min}$, with no further displacement of radioactivity occurring in the subsequent $30 \mathrm{~min}$ of incubation. Second, as shown in Table 3, treatment of the mucosal samples with SBA and soyasaponins did not induce $\left[{ }^{125} \mathrm{I}\right]$ glycinin uptake at $4^{\circ} \mathrm{C}$.

The combined effect of SBA and soyasaponins on the mucosal uptake of $\left[{ }^{125} \mathrm{I}\right]$ glycinin was investigated further, as shown in Figure 2. The concentration of soyasaponins was held constant $(1 \mathrm{mg} / \mathrm{ml})$, whereas that of SBA was raised from 1 to $100 \mu \mathrm{g} / \mathrm{ml}$. SBA did not influence the effect of soyasaponins on glycinin uptake up to $15 \mu \mathrm{g} / \mathrm{ml}$ lectin. Further increases in lectin concentration caused a progressive stimulation of saponin-induced uptake of glycinin, which reached a maximum at approximately 50 $\mu \mathrm{g} / \mathrm{ml}$ lectin. An enhanced uptake of the macromolecule was also seen with SBA alone at concentrations above $35 \mu \mathrm{g} / \mathrm{ml}$; however, as shown in previous experiments, the effect of the combined soy components was greater than the sum of their individual effects.

Dose-response experiments were also performed with respect to the effect of soyasaponins on the $\left[{ }^{125}\right.$ I] glycinin uptake in the presence of $50 \mu \mathrm{g} / \mathrm{ml} \mathrm{SBA} \mathrm{(Fig.} \mathrm{3).} \mathrm{The} \mathrm{average} \mathrm{maximal} \mathrm{coop-}$ erative stimulation of uptake was reached at saponin concentrations of approximately $300 \mu \mathrm{g} / \mathrm{ml}$; however, the large range in responses did not allow us any further definition of concentration relationships for the mucosal interactions of lectin and amphiphile.

The specificity of the SBA stimulation of the mucosal uptake of glycinin was assessed by measuring the blocking action of DGalNAc using L-rhamnose as the control sugar. As shown in

Table 2. $\int^{125} I J$ Glycinin uptake into rabbit jejunal mucosa in vitro

$\begin{array}{cc}\text { Added to mucosal samples } & \\ \left(1 \mathrm{~h}, 25^{\circ} \mathrm{C}\right) & {\left[{ }^{125} \mathrm{I}\right] \text { Glycinin uptake }{ }^{2}} \\ (\mathrm{cpm} / \mathrm{mg} \text { protein })( \pm \mathrm{S} . \mathrm{E})\end{array}$

$\begin{array}{lrc}{\left[{ }^{125} \text { I] Glycinin + buffer }\right.} & 31 & (12) \\ {\left[{ }^{125} \text { I]Glycinin + SBA }\right.} & 161 & (102)^{3} \\ {\left[{ }^{125} \text { I] Glycinin + soyasaponins }\right.} & 230 & (118)^{4} \\ {\left[{ }^{125} \text { I] Glycinin + SBA + soya- }\right.} & 992 & (226)^{5}\end{array}$

saponins

${ }^{1}\left[{ }^{125} \mathrm{I}\right]$ Glycinin $\left(15 \mathrm{pmoles} / \mathrm{ml} ; 1 \times 10^{-5} \mathrm{cpm} / \mathrm{pmole}\right) ; \mathrm{SBA}(50 \mu \mathrm{g} / \mathrm{ml}) ;$ soyasaponins $(1 \mathrm{mg} / \mathrm{ml})$.

${ }^{2}\left[{ }^{125} \mathrm{I}\right]$ was measured on triplicate mucosal samples from each of nine animals after $1 \mathrm{~h}$ of incubation (for details see Table 1 and under "Materials and Methods").

Significance of difference with control $\left(\left[{ }^{125} \mathrm{I}\right] \mathrm{glycinin}+\right.$ buffer $)$ (two-tail $t$ test): ${ }^{3} P<0.05 ;{ }^{4} P<0.005 ;{ }^{5} P<0.0001$.

Table 1. DNA and protein synthesis in rabbit jejunal mucosa maintained in organ culture after treatment with SBA and/or soyasaponins ${ }^{1}$

Radioactivity in TCA homogenates (cpm/mg protein)

$\left[{ }^{14} \mathrm{C}\right]$ Leucine

\begin{tabular}{|c|c|c|c|c|c|c|}
\hline \multirow{2}{*}{$\begin{array}{l}\text { Added to mucosal sam- } \\
\text { ples }^{2}\end{array}$} & & \\
\hline & Insoluble & Soluble & Ins/Sol & Insoluble & Soluble & Ins/Sol \\
\hline${ }^{125}$ I]Glycinin, buffer & $4486 \pm 1760$ & $3051 \pm 1229$ & $1.47 \pm 0.13$ & $3555 \pm 1550$ & $3450 \pm 1679$ & $1.03 \pm 0.12$ \\
\hline${ }^{125}$ I] Glycinin, SBA & $4730 \pm 1508$ & $2200 \pm 807$ & $2.15 \pm 0.39^{4}$ & $3485 \pm 1690$ & $3057 \pm 1439$ & $1.14 \pm 0.12^{3}$ \\
\hline $\begin{array}{l}\left.{ }^{125} I\right] \text { Glycinin, soyasapo- } \\
\text { nins }\end{array}$ & $4530 \pm 1990$ & $3018 \pm 1382$ & $1.50 \pm 0.17^{3}$ & $3865 \pm 1170$ & $3545 \pm 1089$ & $1.09 \pm 0.05^{3}$ \\
\hline${ }^{125}$ I] Glycinin, SBA, soy- & $5303 \pm 1943$ & $2146 \pm 692$ & $2.47 \pm 0.44^{5}$ & $3809 \pm 1580$ & $3227 \pm 1352$ & $1.18 \pm 0.15^{3}$ \\
\hline
\end{tabular}
asaponins

${ }^{\prime}$ Six mucosal samples from each of nine animals were incubated for $1 \mathrm{~h}\left(25^{\circ} \mathrm{C}\right)$ with $\left[{ }^{125} \mathrm{l}\right] \mathrm{glycinin}, \mathrm{SBA}$ and saponins as indicated in the first column. Three of the six samples were then transferred to organ culture dishes and cultured for $4 \mathrm{~h}$ as described in "Materials and Methods." $\left[{ }^{14} \mathrm{C}\right]$ Leucine $(1$ $\mu \mathrm{Ci} / \mathrm{ml})$ and $\left[{ }^{3} \mathrm{H}\right]$ thymidine $(1 \mu \mathrm{Ci} / \mathrm{ml})$ were added during the last $30 \mathrm{~min}$ in culture. Acid insoluble and acid soluble radioactivity were measured as described in "Materials and Methods." Each value represents mean \pm 1 S.D. for 27 mucosal explants from nine animals (except for one set of three SBA-treated explants, which was lost by accident).

${ }^{2}\left[{ }^{125} \mathrm{I}\right]$ Glycinin $\left(15\right.$ pmoles; $\left.1 \times 10^{5} \mathrm{cpm} / \mathrm{pmole}\right) ;$ SBA $(50 \mu \mathrm{g} / \mathrm{ml})$; soyasaponins $(1 \mathrm{mg} / \mathrm{ml})$.

Significance of differences with control $\left(\left[{ }^{125} \mathrm{I}\right]\right.$ Glycinin, buffer), (two-tail $t$ test): ${ }^{3} P$, not significant; ${ }^{4} P<0.025 ;{ }^{5} P<0.005$ 


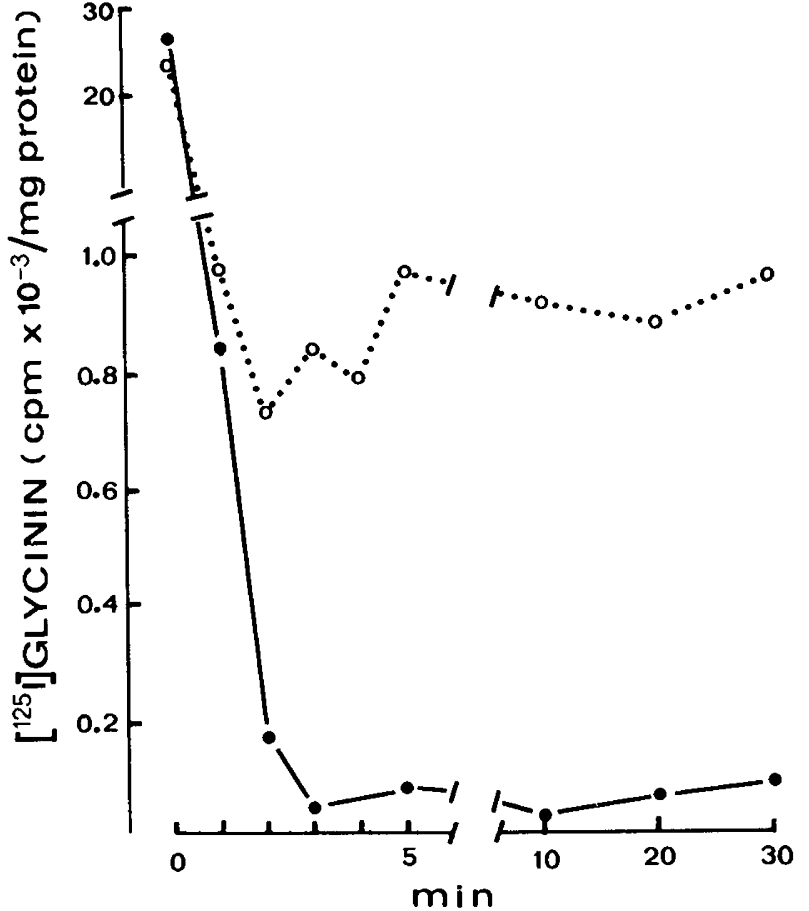

Fig. 1. Mucosal samples from the proximal jejunum were incubated with $\left[{ }^{125} \mathrm{I}\right]$ glycinin $\left(15\right.$ pmoles; $1 \times 10^{5} \mathrm{cpm} /$ pmole) $(-)$, or $\left[{ }^{125} \mathrm{I}\right]$ glycinin, SBA $(50 \mu \mathrm{g} / \mathrm{ml})$ and soyasaponins $(1 \mathrm{mg} / \mathrm{ml}) \bigcirc \ldots O)$, as described under "Materials and Methods." After $1 \mathrm{~h}$ of incubation, the samples were transferred, without previous washing to wells of multiwell plates containing $2 \mathrm{ml}$ of $1 \mathrm{mg} / \mathrm{ml}$ unlabeled glycinin in PBS pH 7.4 at $4^{\circ} \mathrm{C}$ and swirled continuously on a rotary shaker $(130 \mathrm{rpm})$ for variable periods. At the times indicated on the abscissa, the samples were removed, rinsed once with $4 \mathrm{ml}$ of PBS, processed and counted as described under "Materials and Methods." Each experimental point represents six mucosal samples pooled for counting (one animal).

Table 3. Effect of temperature on $\left[^{125}\right.$ IJglycinin uptake into rabbit jejunal mucosa in vitro

\begin{tabular}{|c|c|c|c|}
\hline \multirow{2}{*}{$\begin{array}{l}\text { Added to mucosal } \\
\text { samples }^{1}(1 \mathrm{~h}) \\
{\left[{ }^{125} \mathrm{l}\right] \text { Glycinin }+ \text { buffer }}\end{array}$} & \multirow{2}{*}{$\frac{\text { Temperature }\left({ }^{\circ} \mathrm{C}\right)}{4}$} & \multicolumn{2}{|c|}{$\begin{array}{c}{\left[{ }^{125} \mathrm{I}\right] \text { Glycinin uptake }} \\
(\mathrm{cpm} / \mathrm{mg} \text { protein }) \\
(+\mathrm{SEM})\end{array}$} \\
\hline & & 46 & (13) \\
\hline $\begin{array}{l}{\left[{ }^{125} \text { I]Glycinin + SBA }\right.} \\
+ \text { soyasaponins }\end{array}$ & 4 & 31 & $(16)^{3}$ \\
\hline$\left[{ }^{125} \mathrm{I}\right]$ Glycinin + buffer & 25 & 59 & (7) \\
\hline $\begin{array}{l}{\left[{ }^{125} \mathrm{I}\right] \text { Glycinin + SBA }} \\
+ \text { soyasaponins }\end{array}$ & 25 & 721 & $(221)^{4}$ \\
\hline$\left[{ }^{125} \mathrm{I}\right]$ Glycinin + buffer & 37 & 30 & (11) \\
\hline $\begin{array}{l}{\left[{ }^{125} \mathrm{I}\right] \text { Glycinin + SBA }} \\
+ \text { soyasaponins }\end{array}$ & 37 & 881 & $(166)^{4}$ \\
\hline
\end{tabular}

${ }^{1}\left[{ }^{125} \mathrm{I}\right]$ Glycinin $\left(15\right.$ pmoles; $\left.1 \times 10^{5} \mathrm{cpm} / \mathrm{pmole}\right) ;$ SBA $(50 \mu \mathrm{g} / \mathrm{ml})$; soyasaponins $(1 \mathrm{mg} / \mathrm{ml})$.

${ }^{2}\left[{ }^{125} \mathrm{I}\right]$ was measured on six mucosal samples from three animals as described under "Materials and Methods."

Significance of difference with control $\left(\left[{ }^{125} \mathrm{r}\right]\right.$ glycinin, + buffer) (two tail $t$ test $)$, df $=5:{ }^{3} P$, not significant; ${ }^{4} P<0.005$.

Figure 4, D-GalNAc, but not L-rhamnose, completely blocked both a small direct effect of SBA on $\left[{ }^{125} \mathrm{I}\right]$ glycinin uptake, as well as the larger uptake which occurred in the presence of saponins.

\section{DISCUSSION}

In this work, the use of $\left[{ }^{125} I\right]$ glycinin as a macromolecular tracer has allowed us to show a marked cooperative effect of SBA and soyasaponins on rabbit jejunal mucosal permeability in vitro. The effect of SBA showed concentration dependence and sugar specificity suggesting a role of SBA binding to terminal saccharide sites at the intestinal surface. One possible explanation for the observed cooperative phenomenon is that SBA disturbs the enterocyte apical membrane by binding to reactive sites and that this in turn increases the membrane sensitivity to soyasaponins. Such a mechanism is represented in Figure 5, where we have assumed a crenator effect (12) of soyasaponins on the membrane bilayeran effect similar to that shown previously for saponins in general on cell populations $(9,11,13,14)$. Glycinin leakage into the epithelium would occur at the points of saponin attack on the membrane.

Two observations regarding the effect of SBA on the mucosal uptake of glycinin need further explanations. First, SBA at low concentrations $(<25 \mu \mathrm{g} / \mathrm{ml})$ did not stimulate glycinin uptake

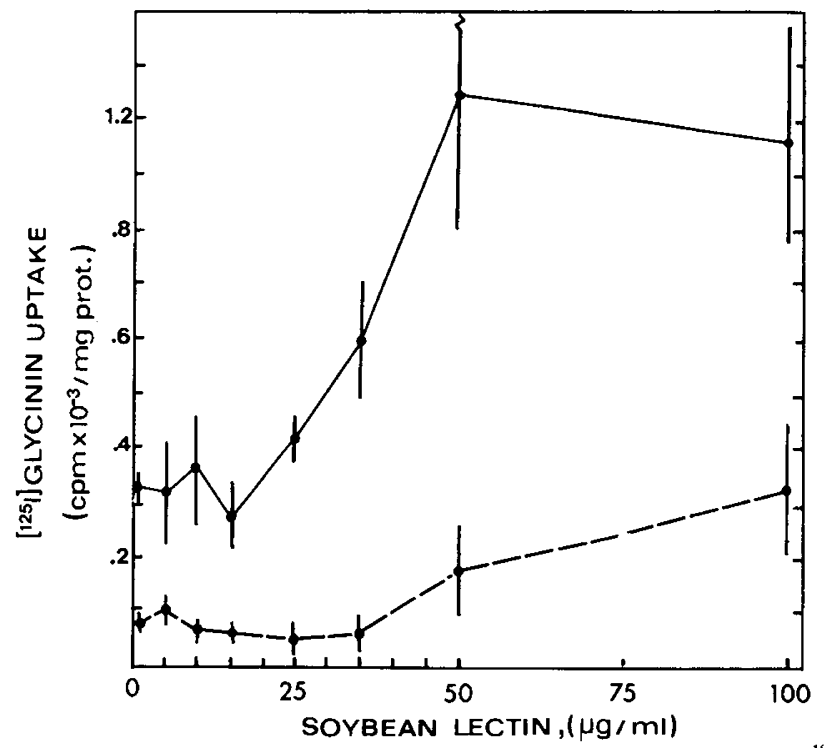

Fig. 2. Effect of soybean lectin concentration on the uptake of $\left[{ }^{125} \mathrm{I}\right]$ glycinin into rabbit jejunal mucosa. Triplicate mucosal samples of proximal jejunum were incubated $\left(1 \mathrm{~h}, 25^{\circ} \mathrm{C}\right)$ in $1 \mathrm{ml}$ of RPMI 1640 containing $\left[{ }^{125} \mathrm{I}\right]$ glycinin $\left(15 \mathrm{pmoles} ; 1 \times 10^{5} \mathrm{cpm} / \mathrm{pmole}\right)$, soybean lectin $(0-100 \mu \mathrm{g})$, and buffer $(-\infty)$ or soyasaponins $(1 \mathrm{mg} / \mathrm{ml})(-)$. (For details, see "Materials and Methods). Results are mean \pm 1 S.D. from experiments on four animals.

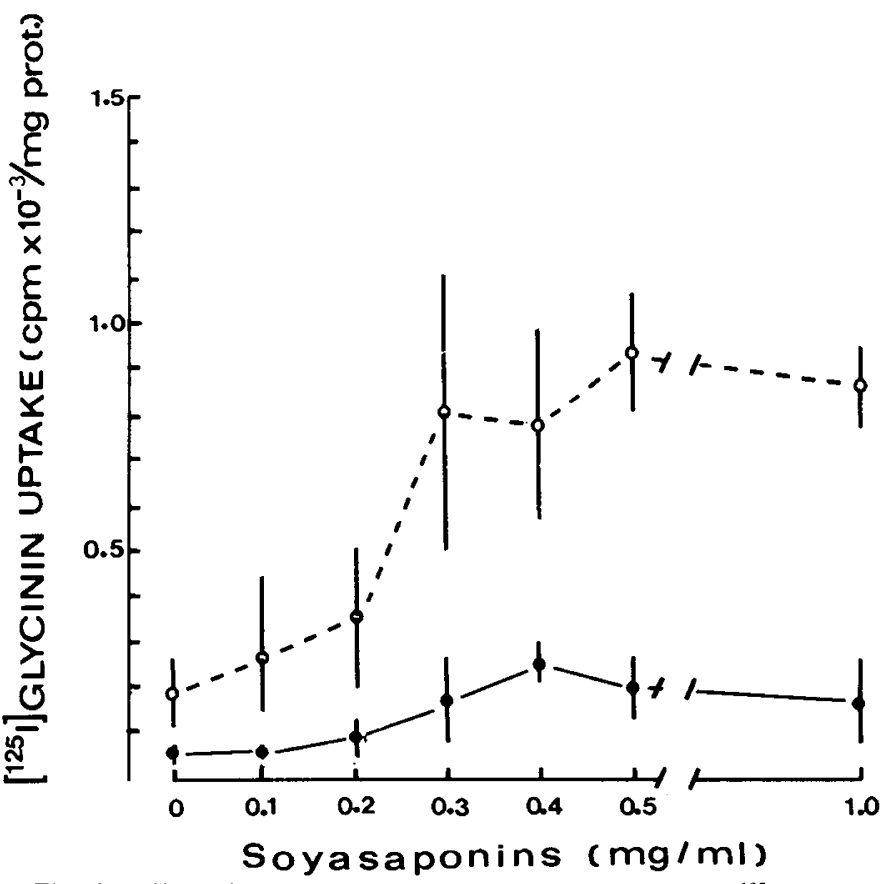

Fig. 3. Effect of soyasaponin concentration on uptake of $\left[{ }^{125} \mathrm{I}\right]$ glycinin into rabbit jejunal mucosa. Triplicate mucosal samples were incubated (1 $\mathrm{h}, 25^{\circ} \mathrm{C}$ ) in $1 \mathrm{ml}$ of RPMI 1640 containing [ [ $\left.{ }^{125} \mathrm{I}\right]$ glycinin ( 15 pmoles; $1 \times$ $\left.10^{5} \mathrm{cpm} / \mathrm{pmole}\right)$, soyasaponins $(0-1 \mathrm{mg} / \mathrm{ml})$, and buffer $(\Theta)$ or SBA (50 $\mu \mathrm{g} / \mathrm{ml})(\bigcirc)$. Results are mean \pm S.D. from four animals. 


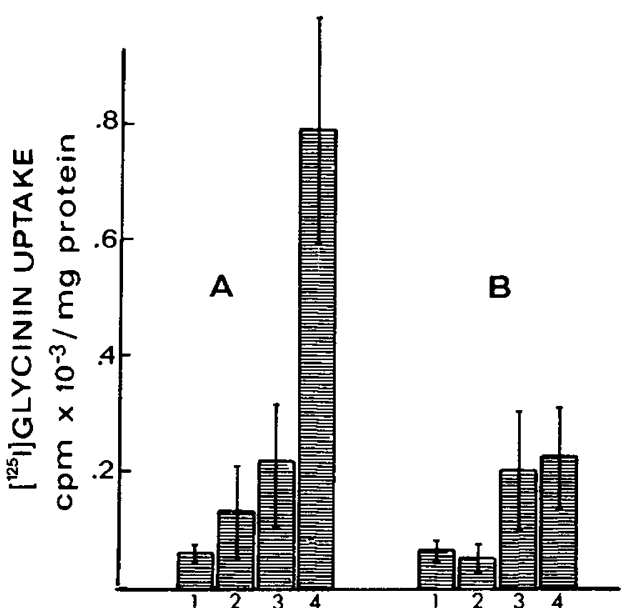

Fig. 4. Inhibition by D-GalNAc of SBA effect on the $\left[{ }^{125} I\right]$ glycinin uptake into rabbit jejunal mucosa. The mucosal samples were incubated $\left(1 \mathrm{~h}, 25^{\circ} \mathrm{C}\right)$ in $1 \mathrm{ml}$ of RPMI 1640 containing $100 \mathrm{mM} \mathrm{L}$-rhamnose (A) or $100 \mathrm{mM}$ D-GalNAc (B), $\left[{ }^{125}\right.$ I]glycinin ( $\left.15 \mathrm{pmoles}, 1 \times 10^{5} \mathrm{cpm} / \mathrm{pmole}\right)$, and buffer (1), SBA (50 $\mu \mathrm{g})(2)$, soyasaponins (1 mg) (3), or SBA + soyasaponins (4). Results are mean \pm S.E. from four experiments.
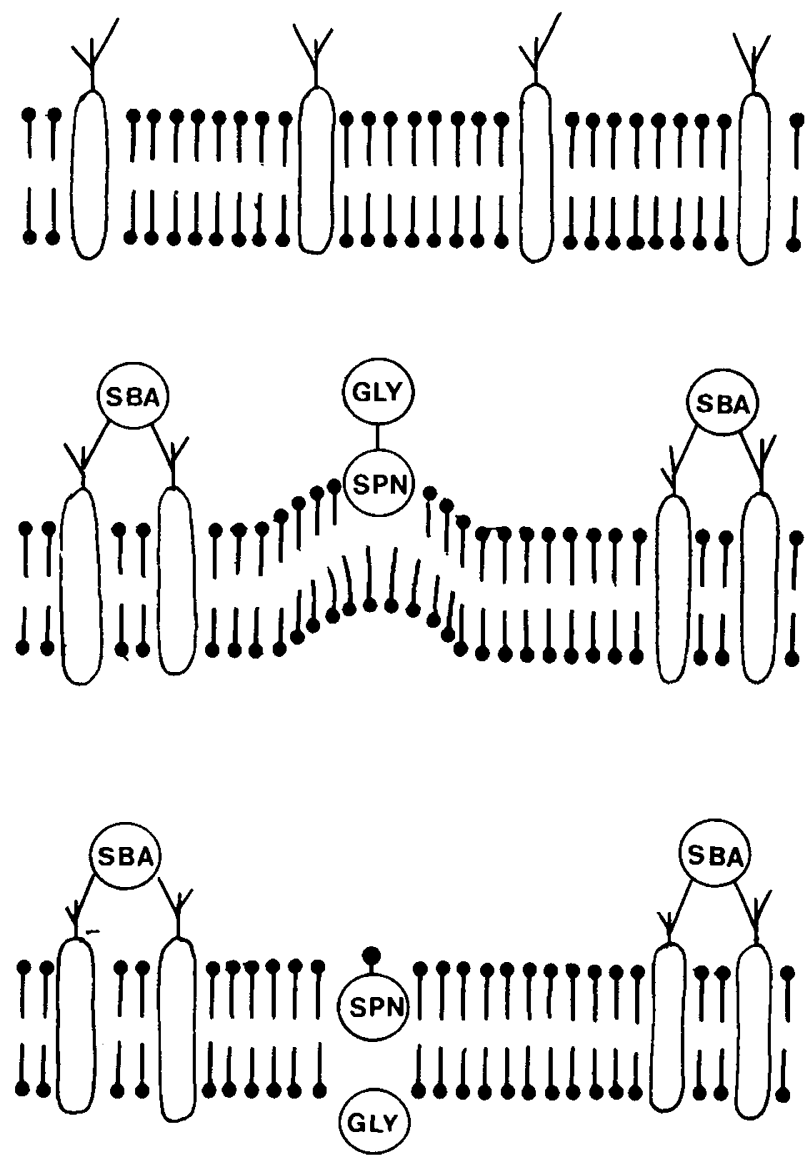

Fig. 5. Hypothetical mechanism of soybean lectin stimulation of the soyasaponin-induced penetration of glycinin into rabbit jejunal mucosa in vitro. SBA (soybean lectin), SPN (soyasaponins), GLY (glycinin).

either when added alone or with soyasaponins. It is not clear if this represented the normal threshold for membrane responsiveness to the lectin, or was due to the presence of some surface mucus that could bind lectin and restrict its contact with the membrane. Second, SBA at higher concentrations $(<35 \mu \mathrm{g} / \mathrm{ml})$ stimulated glycinin uptake in the absence of soyasaponins. This indicated the existence of a second pathway responsive to the SBA interaction. SBA-stimulated endocytosis of glycinin was a distinct possibility, but in preliminary experiments we have been unable to block the response to SBA with cytochalasin B. More detailed studies are indeed needed to clarify this point.

In conclusion, soyasaponins, and SBA were both capable of independently stimulating glycinin uptake into rabbit jejunal mucosa in vitro. The different membrane sites of action of soyasaponins and SBA, and the expected differences in membrane response, suggested separate mechanisms for the induced individual uptakes; however, both agents together exerted a combined stimulation which markedly surpassed the sum of their individual effects. This cooperative effect of lectin and amphiphile revealed concentration dependence and sugar specificity with respect to SBA, suggesting an intervining role of membrane components, but the mechanisms involved cannot be described from the available data.

\section{REFERENCES AND NOTES}

1. Abrahamson, D. R., Powers, A., and Rodewald, R.: Intestinal absorption of immune complexes by neonatal rats: a route of antigen transfer from mother to young. Science, 206: 567 (1979).

2. Badley, R. A., Atkinson, D., Hauser, J., Oldani, D., Green, J. P., and Stubbs, J. M.: The structure, physical and chemical properties of soybean glycinin. Biochim. Biophys. Acta, 412: 214 (1975).

3. Birk, Y.: Saponins in toxic constituents of plant foodstuffs. In: I. E. Liener, Ed., p. 169 (Academic Press, N.Y., 1969).

4. Birk, Y., Bondi, A., Gestetner, B., and Ishaaya, I.: A thermostable hemolytic factor in soybeans. Nature, 197: 1089 (1963).

5. Browning, T. H. and Trier, J. S.: Organ culture of mucosal biopsies of human small intestine. J. Clin. Invest., 48: 1423 (1969).

6. Catsimpoolas, N., Kenny, J. A., Meyer, E. W., and Szuhaj, B. F.: Molecular weight and amino acid composition of glycinin subunits. J. Sci. Food Agric., 22: 448 (1971).

7. Jones, E. A. and Waldmann, T. A.: The mechanism of intestinal uptake and transcellular transport of IgG in the neonatal rat. J. Clin Invest., 51: 2916 (1972).

8. Lotan, R., Siegelman, H. W., Lis, H., and Sharon, N.: Subunit structure of soybean agglutinin. J. Biol. Chem., 249: 1219 (1974).

9. Ohtski, I., Manzi, R. M. Palade, G. E., and Jamieson, J. D.: Entry of macromolecular tracers into cells fixed with low concentrations of aldehydes. Biol. Celluiare, 31: 119 (1978).

10. Rodewald, R.: Intestinal transport of antibodies in the newborn rat. J. Cell Biol., 58: 189 (1973).

11. Seeman, P., Cheng, D., and Iles, G. H.: Structure of membrane holes in osmotic and saponin hemolysis. J. Cell Biol., 56: 519 (1973).

12. Sheetz, M. P. and Singer, S. J.: Biological membranes as bilayer couples. A molecular mechanism of drug-erythrocyte interactions. Proc. Natl. Acad. Sci. USA 71: 4457 (1974).

13. Segal, R. and Nilo-Golzweig, I.: On the similarity of hemolysis induced by plant sapogenins and by neutral steroids. Biochem. Pharmacol. 20: 2163 (1971).

14. Shany, S., Bernheimer, A. W., Grushoff, P. S., and Kim, K-S.: Evidence for membrane cholesterol as the common binding site for cereolysin, streptolysin $\mathrm{O}$ and saponin. Mol. Cell Biochem., 3: 179 (1974).

15. Shimada, Y. and Obinata, T.: Polarity of actin filaments at the initial stage of myofibril assembly in myogenic cells in vitro. J. Cell Biol., 72: 777 (1977).

16. Thanh, V. H. and Shibasaki, K.: Major proteins of soybean seeds. A straight forward fractionation and their characterization. J. Agric. Food Chem., 24: 1117 (1976).

17. Udall, J. N., Pang, K., Fritze, L., Kleinman, R., and Walker, W. A.: Development of gastrointestinal mucosal barrier. I. The effect of age on intestinal permeability to macromolecules. Pediatr.Res., 15: 241 (1981).

18. Udall, J. N., Colony, P., Fritze, L., Pang, K., Trier, J. S., and Walker,W. A.: Development of gastrointestinal mucosal barrier. II. The effect of natural versus artificial feeding on intestinal permeability to macromolecules. Pediatr. Res., 15: 245 (1981).

19. Walker, W. A., Cornell, R., Davenport, L. M., and Isselbacher, K. J.: Macromolecular absorption mechanism of horseradish peroxidase uptake and transport in adult and neonatal rat intestine. J. Cell Biol., 54: 195 (1972).

20. Wolf, W. J. and Thomas, B. W.: Ion-exchange chromatography of soybean saponins. J. Chromatogr., 56: 281 (1971).

21. Zanetta, J. P., Vincendon, G., Mandel, P., and Gombos, G.: The utilization of Idimethylaminonaphtalene-5-sulphomychloride for quantitative determination of free aminoacids and partial analysis of primary structure of proteins. J. Chromatogr., 51: 441 (1970).

22. Requests for reprints should be addressed to: Ramon Torres-Pinedo, M.D., Oklahoma Children's Memorial Hospital, P.O. Box 26307, Oklahoma City, Oklahoma 73126.

23. This research was supported by NIH Grant HD-12441.

24. Presented in part at the meetings of the Society for Pediatric Research, San Francisco, April 27-May 1, 1981.

25. Received for publication June 19, 1981.

26. Accepted for publication March 1, 1982. 